\title{
Development Committee Closing Press Conference
}

October 12, 2013

World Bank Group President, Jim Yong Kim, Managing Director of the International Monetary Fund, Christine Lagarde, and Chairman of the Development Committee, Marek Belka

World Bank/IMF 2013 Annual Meetings

Washington, DC

\section{Transcript}

MR. MILLS: Thank you all for coming to our closing press conference for these Annual Meetings.

Each of our participants, President Kim, Chairman Belka, and Managing Director Lagarde will have an opening statement, and then we'll be happy to take your questions.

If I could just please ask everyone to make sure that their cell phones are off and we'll get right to it.

Chairman Belka.

MR. BELKA: Thank you.

Ladies and gentlemen, welcome to this press conference on today's Development Committee meeting. I'm pleased to be joined by Jim Yong Kim and Christine Lagarde. When Jim became President of the World Bank Group, he launched a major reexamination of the Group's role and strategy, undertaken in close coordination with the Bank's member countries.

Some of you may remember that, in April of this year, the Development Committee endorsed two goals to guide the Bank Group: First, the goal of ending extreme poverty 
within a generation. We supported a global target of reducing the extreme poverty rate, a number of people living on less than $\$ 1.25$ a day to 3 percent by 2030 .

Second, the goal of promoting shared prosperity. This will entail fostering income growth of the bottom 40 percent of the population in every country.

We also emphasized that these two goals must be pursued in a sustainable manner. Over the past six months, we have witnessed intensive consultations and analysis designed to put the flesh on the bones. That is to say, to work out a detailed strategy by which the Bank Group will set out to translate the goals into operational programs with its borrowing member countries.

The World Bank Group's strategy which we endorsed today is being made available to you and to the public. You also have our communique which summarizes the most important points we agreed regarding the strategy.

I'm not going to continue with this and just leave it to Jim and Christine to cover more details of the strategy on the economic context for development.

Thank you.

MR. MILLS: Thank you.

President Kim.

DR. KIM: Yes, thank you very much for coming to this closing press conference. And first, a big thank you to the hardworking staff at the World Bank Group and the IMF who spent long hours in preparing these meetings, some 13,000 people from 185 countries.

Second, far from Washington, I want to express our concern about reports in Eastern India where Cyclone Phailin has made landfall. It's forecast to hit an area populated with 4.5 million people, 150 mile per hour winds. Our thoughts go out to all those living in the cyclone's path.

I am very grateful here at the Annual Meetings for the support of the Governors in unanimously endorsing our World Bank Group strategy. 
For the first time in the history of our organization we have a strategy that leverages the strengths of our entire organization: the Bank, the IFC, our private sector arm, and MIGA, which provides risk guarantees and aligns all our work for a common purpose.

The common purpose is our two goals, endorsed six months ago by our Governors to end extreme poverty by 2030 and to boost shared prosperity of the bottom 40 percent of the population in all developing countries. Now, our strategy will drive all our activities and resources to meet these two goals. This will produce concrete results and maximize our development impact.

I'd like to highlight one major shift that comes from our strategy: We will leverage our fund for the poorest, IDA, to bring in other sources of capital for things like new sources of electricity, schools--and schools, especially in fragile and conflict-affected states. We need a strong IDA17 replenishment in order to fulfill these bold plans that will open up a world of opportunity for the poor and the vulnerable.

Our strategy calls for more investment in fragile states, and it also calls for working on a variety of fronts to combat climate change and to improve health and education systems, especially for the benefit of girls and women.

We now are strongly positioned to draw upon the World Bank Group's comparative advantages. In the coming months and years, the world will see a renewed and revitalized World Bank Group, one that rigorously works to end extreme poverty and boost shared prosperity.

Let me make one other final comment on the continuing fiscal impasse here in Washington. We are now five days away from a very dangerous moment. I urge U.S. policymakers to quickly come to a resolution before they reach the debt ceiling deadline. The closer we get to the deadline, the greater the impact will be for the developing world. Inaction could result in interest rates rising, confidence falling, and growth slowing.

If this comes to pass, it could be a disastrous event for the developing world and that will, in turn, greatly hurt the developed economies, as well.

I urge U.S. policymakers to avert this potential crisis. Thank you very much for your attention.

MS. LAGARDE: Thank you very much. Good afternoon. I'll be brief. 
A few numbers, first. As part of the global outlook, we are focusing in particular this afternoon on some of the low-income countries, the small and fragile states. And clearly, in a way, this is one of the bright spots that we have on the World Economic Outlook.

If we look at the average growth in Sub-Saharan Africa, we have an average growth of 5 percent. The forecast for next year is 6 percent. There are not many areas in the world that have such high growth rates. Given that it's starting from a low base, there is clearly room for development, and that's certainly a goal that, together with the World Bank, we try to be associated with in our capacity.

Now, three areas that I would like to just flag for you.

One is that, going forward, we certainly bring into each and every of our surveillance missions, technical assistance support, we try to bring growth, and we do believe that there are growth-specific issues and initiatives that can be taken in relation to Sub-Saharan African countries, in particular.

The second area that I would like to mention is the degree of technical assistance that we're providing on the ground in a particular domain, one of which is, for instance, raising revenue by Sub-Saharan African governments.

In that respect, we have sent 150 technical assistance missions on the ground for the sole purpose of raising revenue.

And the third thing that I would like to mention, as well, is that we are pleased because after laborious efforts--and it does take time to actually raise revenue-- we have now passed the threshold of 90 percent to replenish the Poverty Reduction and Growth Trust that we use to finance some of our programs for the low-income countries. So, this is now on a sustainable basis, and we're pleased that the membership finally adopted that resolution with this majority.

Thank you.

MR. MILLS: Thank you.

We'd be happy to take some questions.

Yes, ma'am, right here. 
QUESTION: This is Anna Yukhananov, from Reuters.

As we've heard emerging markets are slowing down and also may have to contend with high interest rates with the taper. So, I was wondering if you expect that to make it harder for them to access capital markets and whether the World Bank should play a bigger role in helping them to do that in the future.

DR. KIM: Let me take that. I'm sure Christine may have some thoughts, as well. You know, it was one of the topics of discussion at the G20 Finance Ministers meeting, and specifically we talked about one aspect of this, which is access to long-term capital for infrastructure.

And there was clearly--there was clear consensus in the room that there's a great need for some organization, whether it be the World Bank or not, to think about how to leverage public resources, and this could be everything from official development assistance to a nation's own public resources.

And for organizations like the World Bank, and perhaps the other multilateral development banks, IMF, others, to work to prepare projects and to lower both perceived and real risk in getting the private sector to invest in certain projects. We've already been working to that end, but the needs for infrastructure financing are enormous, something like $\$ 1$ trillion a year, and there's just no way that either official development assistance or public resources alone will meet that need.

But many private sector sources of financing have been staying on the sidelines worried about the risk. So, the task is for us to now think about the mechanics in governments and some sort of facility that would move forward and both bring public resources together, but then figure out ways of de-risking and making more bankable certain major infrastructure projects so that the private sector will both feel more comfortable investing, and that we can actually protect them and ensure that they both generate profit and have, at the same time, a huge development impact.

So, there was consensus that we need to move forward, and the Australian Finance Minister Joe Hockey agreed that this would be on the agenda for the next set of G20 meetings.

MS. LAGARDE: Just maybe very briefly, tapering entails potential rushing out of the capital that went out to these emerging market economies. And clearly, having a deeper capital 
market for those economies is a good way to actually keep those capital from flowing out.

MR. MILLS: Yes, I'll go right here to the second row.

Yes, ma'am.

QUESTION: Thank you. Ilsa Santarita [phonetic] from CNN [unclear] Unit, Mexico City.

Do you have any special observations or recommendations to Mexico in order to protect its economy from the financial volatility, considering the deeply--integration between the United States and Mexico?

Thank you.

MS. LAGARDE: Well, you know, the Mexican economy is quite well anchored, if I may say. You know, it has gone through a lot of restructuring. It has a good predictable monetary and fiscal policy. It embarks on very strong structural reforms that will solidify its economy, added to which, it has the benefit of a Flexible Credit Line (FCL) of significant amount with the IMF, which operates as a guarantee and a seal of the good policies adopted by the Mexican authorities.

So, there has been fluctuation of the peso relative to the dollar from June to August, by about 20 percent, but it has not hurt the Mexican economy that has recovered from that, came September.

So, the economy is--you know, I use "well anchored" because people know that it's solid.

MR. MILLS: Okay. Yes, Danny.

QUESTION: Thank you. Danny Xufeng, with China Xinhua News Agency. The global growth prospect has been lowered again. What does that mean for the policy priorities for each of your agencies in coming years?

Thank you.

DR. KIM: I think he's referring to the WEO, right? So... 
MS. LAGARDE: Okay.

DR. KIM: I'll jump in afterwards.

MS. LAGARDE: We've revised the global growth projection from 3.2 to 2.9 percent. At the same time, we're observing pretty positive developments, if they are continued. One is that advanced economies are picking up a bit, and if the right methods, the right policies, the right decisions are made soon enough, particularly in this country, on the fiscal front, certainly the U.S. economy will pursue its recovery and will not be hit by as much fiscal consolidation next year.

There is that element of transition happening at the moment, and what it means certainly for our institution is that we have to be more and more aware of the spillover effects of decisions made in any particular country, particularly the advanced economies. One of the big debates we had is how much the emerging market economies are preventing damage from being done as a result of the unwinding of unconventional monetary policies. So, we have to help those countries doing that. We have to do better surveillance, better spillover analysis to help them anticipate and build against those potential risks.

But you know, there are still growth rates of significant amount in--you look at China, our forecast is 7.6. The Brazilian economy is, again, consolidating and growing more strongly, and you have multiple examples of that, not to mention the low-income countries that are growing at probably the fastest rate on the globe at the moment.

DR. KIM: And for us, you know, one of the things that we've been clear about--and Christine and I both have been giving this message--is that, especially for developing--I mean, we're still waiting to see what happens at the U.S. situation, but the decision not to decrease bond purchases by the U.S. Fed are giving the emerging markets, we think, at least a couple of month window, and we're urging all the emerging market countries--they know and we've identified for a long time the kinds of fiscal policy reforms, structural reforms, improvements in the business environment. We know, country to country, what they need to do.

We want--we've been very clear in saying, when interest rates were low and it's easier to find capital, many countries said, well--didn't feel the urgency of making those kinds of 
changes. And now, with interest rates having gone up, some of the countries are saying, "Well, we're under too much pressure to make those changes."

And so, with the emerging market countries, some of them, for example, despite lower growth rates, China is continuing with its transition from an export and investment-oriented economy now to one more based on consumption and services, and the Chinese have clearly signaled that they want to continue, and we applaud that.

I met with the Minister of Finance of Indonesia. They had a very strong response to the regional spike in interest rates and the drop in the value of their currency, and we encouraged them to continue and move even more quickly to continue those reforms.

So, for us, the advice is very clear, that what happened with the spike in interest rates is that it really uncovered weaknesses in emerging market economies, and now we are very strongly urging these emerging market economies to really move quickly on the reforms that we all know that they have to make.

MR. MILLS: Yes, we'll go to the gentleman in the--yes, in the fourth row.

QUESTION: [Through interpretation] Good afternoon. Jesus Antonio Vargas. I come from Medellin, Colombia.

This week has been absolutely fantastic. It's been a fast course in acrobatics, because in more than one occasion you've spoken of balance.

I would also like to congratulate the President of the World Bank because he touched upon the topic of clean and livable cities, a challenge that I'm sure many countries face.

However, Dr. Lagarde, why did you not talk about Urga [phonetic] which is what is truly going to give stability to countries and allow them to set the foundation for tomorrow?

And lastly, Monsignor Jose Enrique Rios [phonetic] from Medellin would like to say that in Washington you basically are the popes of the world economy.

Thank you.

MR. MILLS: Okay. Yes, Sandrine-

INTERPRETER: The question was about savings. 
QUESTION: For Mr. Kim, and one for Mr. Belka.

Mr. Kim, as part of your strategy, I was wondering, we talked with the Finance Ministers from Africa this morning, and they told us that you promised to cut your delivery time. Is this part of your strategy, and how do you plan to manage that?

Let's say, if you could take a concrete example of how you're going to get there.

And for Mr. Belka, I was just wondering, we heard Mr. Kim talking about this two- to threemonth window to take measures. How about Poland? Do you feel you've taken all the measures you need to be protected from a potential tapering effect?

DR. KIM: Let me start, while Marek thinks about his response.

[Laughter.]

DR. KIM: So, one of the things that we're doing, and we talked about it in the speech was we're creating a presidential delivery unit. And what we know is that there are many, many steps from conception of a project to actual delivery, and we are looking at every single one of those steps to see which ones are absolutely necessary and which ones are adding layers of bureaucracy that aren't necessary.

Now, in my view, you can look at that, but if you look at it with no clear target, no clear outcome that you're looking for, there are ways of justifying any number of processes.

So, in speaking with my senior staff, we set a goal that we're going to cut the time, the average time from conception to delivery a third over the next two years.

So, this is a very difficult target, but my guess is that, with that target in sight, we're going to look very differently at the things that we think are necessary and the things we think are not.

And I will follow the speed and how far we're getting--I will follow it from my office as part of the presidential delivery unit.

MR. BELKA: Well, what we have established many times is that, in times of financial turbulence, global factors dominate over domestic factors, which means if something goes wrong in the world, both exchange rate market or sovereign debt market suffers, but it 
rebounds when good times--when good times come, and it--they--both markets rebound even more if you have good fundamentals, because in sort of calm times, domestic factors try to, if not dominate, then they sort of come to the fore.

But just one more remark to the previous questions. Many were concerned about the impact of growing interest rates on emerging markets. I think that, as complicated as reality is, we can simplify it along the following lines:

It depends on whether the rising interest rates are the sign of improving health of the global economy or improving health of advanced countries. Or are they a sign of market turbulence?

If the former is the case, then we can say--well, we can say this is a symptom of normalizing markets, and it's good news, basically, for emerging markets.

If the latter, however, is the case, then it's bad news. That is why we--I mean, both organizations put so much stress on advising the countries engaging in unconventional monetary policy in orderly exiting those--UMPs, yes?

MS. LAGARDE: Yes.

MR. BELKA: I know how important--yeah, how important this acronym is for you. [Laughter.]

MR. MILLS: Okay. We'll have one more question.

Yes, ma'am. If you could wait for the microphone.

QUESTION: $\mathrm{Hi}$, my name is Ri Xijao [phonetic] from China Central Television.

My first question is for President Jim Yong Kim. As we know, you mentioned several times this week that the threat of U.S. default could hurt emerging markets. And we know that, today, the U.S. Congressmen are still discussing this issue. What kind of advice can you give to the emerging markets and also the United States?

And also my second question is for Director Christine Lagarde. And we know that China is one of the members of the development Committee. What kind of role China, do you think, played this year?

Thank you so much. 
DR. KIM: Well, first, let me start by saying that the one thing I would say to policymakers is the same thing l've been saying: Please keep talking and please understand that the decisions you make, the agreements you come to or don't come to, are going to have a global impact.

And the other point that we make is that the U.S. Chamber of Commerce says that more than 50 percent of all exports are to developing countries. So, this is not just that it's going to have a negative impact on developing countries, it's going to have a direct negative impact on exports in the United States.

And so, we just urge them to continue talking and come to a solution.

And in terms of what we tell emerging markets, it's the same advice, that there is going to be turbulence, there are going to be difficulties, and therefore it's always the right time to move forward with the reforms that everyone knows you have to make. And so, we stand ready to help in terms of providing technical assistance for developing economies. But now is always the time to make the reforms that you need to make.

MS. LAGARDE: As to your question about China, China is an excellent partner in all the debates, all the discussions we have in the course of those Annual Meetings, and it is always a pleasure to have their contribution and to have that second largest economy of the world play such an active role.

MR. MILLS: Thank you very much, everyone. 